\title{
Effect of the Prohibition of Board Members of Joint Stock Companies from Participating in Negotiations (TCC 393) on Quorums
}

\author{
İbrahim Çağrı Zengin* (1)
}

\begin{abstract}
Provision of TCC 393 which prohibits members of a board of directors from participating in negotiations on matters where the personal interests of themselves and their relatives' listed in the law, and their interest outside the company, conflict with the company's interests, and in our opinion from voting in a vote on the relevant matter, is not an absolute mandatory regulation. In this context, violation of this provision would not invalidate the board of directors' resolution, but it only causes a compensation liability (TCC 393/2). Accordingly, if the prohibited member attends the meeting or casts a vote despite the prohibition, then such participation shall be taken into consideration in determining and calculating the meeting and decision quorums. However, in order to protect the behaviour of members who, in compliance with the prohibition, does not participate in discussion of the relevant agenda item and the voting, and in order not to make it disadvantageous to comply with the law compared to non-compliance, and to make it possible to resolve in such case, it would be an appropriate solution to drop the prohibited member or members who do not attend the meeting and cast a vote, from the meeting and decision quorum, and to calculate the quorums accordingly. Such prohibition and its consequences would also be fully applicable to the method of resolving through circulation within the scope of TCC 390/4, and it is mandatory to send the written resolution proposal to the prohibited member or members also, to resolve through such a method.
\end{abstract}

\section{Keywords}

Prohibition of participating in negotiations, Board of directors, Meeting quorum, Decision quorum, Quorum

Anonim Ortaklıklarda Yönetim Kurulu Üyelerinin Müzakereye Katılma Yasağının (TK 393) Yeter Sayılara Etkisi

Öz

Yönetim kurulu üyelerinin, kendilerinin veya kanunda sayılan yakınlarının kişisel ve şirket dışı menfaatleri ile ortaklığın menfaatinin çakışţ̆̆ı konulara ilişkin müzakerelere katılmasını ve benimsediğimiz görüşe göre ilgili konuya yönelik oylamada oy kullanmasını yasaklayan TK 393 hükmü mutlak emredici bir düzenleme değildir. Bu kapsamda hükme aykırılık yönetim kurulu kararının geçersizliğine neden olmaz, yalnızca bir tazminat sorumluluğunun doğmasına yol açar (TK 393/2). Bu niteliği gereği, yasaklı üye, yasağa rağmen toplantıya ve oylamaya katılmış ise, söz konusu katılım toplantı ve karar yeter sayılarının belirlenip hesaplanmasında dikkate alınır. Ancak yasağa uyarak ilgili gündem maddesinin görüşülmesine ve oylanmasına iştirak etmeyen üyelerin bu davranışının korunması ve kanuna uygun davranmanın uymamaya nazaran dezavantajı hâle getirilmemesi, ayrıca böyle bir durumda da karar alabilmenin olanaklı kılınabilmesi için, toplantiya ve oylamaya katılmayan yasaklı üye veya üyelerin toplant ve karar nisabının matrahından düşülmesi ve aranacak yeter sayıların buna göre hesaplanması uygun bir çözüm olacaktır. Söz konusu yasak ve sonuçları, TK $390 / 4$ kapsamında elden dolaştırma yoluyla karar alınması yönteminde de aynen uygulama alanı bulacağı gibi, bu usulde karar alınabilmesi için yazılı karar önerisinin yasaklı üye ya da üyelere de gönderilmesi zorunludur.

\section{Anahtar Kelimeler}

Müzakereye katılma yasağı, Yönetim kurulu, Toplantı yeter sayısı, Karar yeter sayısı, Nisap

* Corresponding author: Ibrahim Çağrı Zengin (Res. Asst. PhD), Istanbul University, Faculty of Law, Department of Commercial Law, Istanbul, Turkey. E-mail: iczengin@istanbul.edu.tr ORCID: 0000-0002-2196-2300

Citation: Zengin IC, "Effect of the Prohibition of Board Members of Joint Stock Companies from Participating in Negotiations (TCC 393) on Quorums" (2020) 78(4) İstanbul Hukuk Mecmuası 1747. https://doi.org/10.26650/mecmua.2020.78.4.0002 


\section{Extended Summary}

Article 393/1 of Turkish Commercial Code stipulates that a member cannot participate in negotiations related to a board of directors' resolution to be taken on a matter where the noncompany-related personal interests of the members or their relatives listed in the law conflict with the company's interests. As it is clearly understood from its express wording, this provision primarily covers the participation, by the relevant board member, in the discussion of the agenda item of the board of directors' meeting which causes the prohibition. Despite the silence of the lawmaker on this subject, doctrine considers that one who cannot participate in discussion should not be allowed to cast vote. As a result, the prohibition stipulated in TCC $393 / 1$ covers not only the participation to negotiations but also to voting process.

The legal nature of TCC 393/1 provision is controversial. According to one view the provision is absolutely mandatory and a resolution taken in breach of this prohibition should be null and void. Another opinion -that we adopt- in Turkish doctrine considers TCC 393/1 as a non-mandatory provision, violation of which causes only a compensation liability, as TCC 393/2 states that "( $(t)$ he board member who acts in breach of this provisions and the members who do not object to attendance of the relevant member at the meeting although there is a known objective conflict of interest, and the board members who take a decision on attendance of such member at the meeting shall be obliged to compensate the company against losses incurred thereby".

The judicial practice is also not consistent on the matter. In some orders of the Supreme Court, it is said that attendance at the meeting, of a board member who shouldn't attend the meeting within the scope of the prohibition from attending the negotiation, would not invalidate the decision taken, but only create compensation liability of the relevant member, while some other orders mention nullity of the board of directors' resolution.

TCC has no provision on the effect of the prohibition of board members from participating in negotiations and from cast vote, on meeting and decisions quorums. The opinion that considers TCC 393/1 as an absolute mandatory provision that invalidates the decision upon its violation, takes an approach similar to "effect rule" in TCC 446/1-b, with regard to the effect of provision on the quorums, and considers that if it can be concluded that the decision complies sufficient meeting and decision quorums without attendance and vote of the member who actually attends the discussions and votes in favour of the decision (so with the attendance of other members and their votes in favour of the decision), then mere attendance at the meeting and voting despite the prohibition would not affect the validity of decisions taken, but otherwise, i.e. if the prohibited member has had an "effect" on taking the decision, then it would be required to deem the decision invalid. According to the other view, TCC $393 / 1$ provision should not be considered as a quorum matter; consequently the prohibition should not have any effect on the rules related to determining and calculating the quorums.

In our opinion, TCC 393 is not absolutely mandatory and as violation of the provision does not invalidate the decision made, the prohibited member who participate and cast 
vote should be taken into consideration in calculation of meeting and decision quorums. However, this approach does not satisfy the sense of law fully, as the obeisance of law would be disadvantageous than its violation. In order to overcome this injustice, it would be the most solution in our view, considering the balance of interests and sense of justice, to take account of the prohibited members in the meaning of TCC 393, in determining quorums, when they attend the meeting and vote despite the prohibition, and not take them into account in determining quorums when they do comply with the prohibition and not attend the meeting and vote, and that the quorums must be calculated over the number found by deducting such members from the total. 


\section{Introduction}

As an exception ${ }^{1}$ to the board members' liability to personally attend meetings and cast votes ${ }^{2}, \mathrm{TCC}^{3} 393 / 1$ stipulates that a member cannot participate in negotiations related to a board of directors' resolution to be taken on a matter where the non-companyrelated personal interests of the members or their relatives listed in the law conflict with the company's interests. This provision addresses the concerns that, as a rule, a board member who has a conflict of interest with the company cannot act impartially, may prioritize own interests over the company's interests, and may also direct other members in his/her favour or may create such an impression on other members ${ }^{4}$.

While TCC 393, dedicated to prohibition of participating in negotiations, contains provisions in the scope of such prohibition (TCC 393/1), sanction of violation of the prohibition (TCC 393/2) and notification obligations (TCC 393/3), there is no clarity as to how concretely the prohibition is to be applied, more particularly, whether the meeting and decision quorums would be affected if the prohibited member or members comply with the law and do not attend the meeting and cast a vote, or does indeed attend and vote in breach of the provision; in other words, how the quorums are to be calculated in the said cases.

This study discusses the effect of the prohibition from participating in negotiations, on the board of directors' meeting and decision quorums.

\section{Scope of the Prohibition}

\section{A. Participation in the Negotiation (Discussions)}

As easily understood from the title line of TCC 393 which is deemed included in the text (TCC 1534/1), and from the express wording of the entire provision, the provision primarily covers the participation, by the relevant board member, in the discussion of the agenda item of the board of directors' meeting which causes the prohibition. As part of the "decision making process in the broad sense", discussions is the stage where the board members express and discuss opinions on the matter, thus making up their mind, after commencement of the meeting and before voting the relevant agenda item ${ }^{5}$.

\footnotetext{
Hülya Çoştan, 'Yönetim Kurulunun Karar Alma Usulleri, Oy Hakkı, Yetersayılar ve Toplantı Talep Hakkı' (2012) 28 (3) Batider 155, 177.

2 See Oğuz İmregün, 'Anonim Ortaklıklarda Yönetim Kurulu Toplantı ve Karar Yetersayıları ve Yönetim Kurulu Kararlarına Karşı Başvuru Yolları' in Abuzer Kendigelen (ed), Prof. Dr. Hayri Domaniç'e 80. Yaş Günü Armağanı (Beta 2001) 286; İsmail Kırca (Feyzan Hayal Şehirali Çelik and Çağlar Manavgat), Anonim Şirketler Hukuku, C. 1, Temel Kavram ve İlkeler, Kuruluş, Yönetim Kurulu (BTHAE 2013) 493-494.

3 Turkish Commercial Code, Law Number: 6102, Date of Enactement: 13.01.2011, OG 14.02.2011/27846.

4 See Hayri Domaniç, Anonim Şirketler Hukuku ve Uygulaması, TTK. Şerhi II (Yaylacık Matbaası 1988) 615; Kırca (Şehirali Çelik and Manavgat) (n 1) 493; Necla Akdağ Güney, Anonim Şirket Yönetim Kurulu (2nd, Vedat 2016) 208-209.

5 For detailed information and description on decision-making stages in broad and narrow sense see Hâluk Nami Nomer, Kişi Birliklerinde Genel Kurul Kararlarının Geçersizliğine Illişkin Temel Esaslar (Beta 2008) 46-47; also see Kırca (Şehirali Çelik and Manavgat) (n 1) 499.
} 
This prohibition is only limited to the relevant agenda item. In other words, at a board of directors meeting having several agenda items, it is necessary and sufficient that the board member does not attend the discussion of the subject causing the conflict of interest, i.e. the application of TCC 393; this does not prevent the member from participating in the negotiation of other agenda items, if any ${ }^{6}$.

\section{B. Participation in Voting}

Although TCC 393/1-s.1 only contains the expression that "cannot participate in negotiations", doctrine considers the protection purpose of the provision and that it would not a fortifori possible to cast votes where participating in discussions is prohibited, and that, as well as non-attendance of the relevant member at the negotiations, voting on that agenda item would also be covered by the prohibition ${ }^{7}$.

In addition to these justifications, with which we also agree, the wording of the provision also justifies this conclusion, in our opinion. That is to say, TCC 393/1s.3 stipulates that, in case of doubt, the decision is to be made by the board of directors ("doubt voting"), and TCC 393/1-s.4 states that the relevant member cannot participate in such voting "as well”. As the lawmaker states that the relevant member cannot vote in such "doubt voting" "as well", this means that it is initially accepted that the issue of not casting vote is already present beforehand, so that the relevant member does not cast at the doubt voting as well. In the context of prohibition from participating in negotiations, the only case where voting may be the case in states before doubt voting is the voting on the board of directors' resolution, regarding the matter where the relevant member is prohibited from (TCC 393/1-s.1) therefore it is inevitable to conclude that the lawmaker provides for a vote prohibition, both in that voting and the doubt voting. In brief, it should be accepted that TCC 393 prohibits the relevant member from both attending the negotiations and voting at the subsequent voting, on matters covered by the prohibition of the provision.

\section{Legal Nature of TCC 393/1 Provision}

Considering the expressions "board member ... cannot participate in negotiations. ... (M)ember ... is required to observe the prohibition" in TCC 393/1, it is possible to initially infer that the provision is absolutely mandatory. This would also be

\footnotetext{
See Kırca (Şehirali Çelik and Manavgat) (n 1) 496; also see Imregün stating that the members who cannot participate in the discussions according to former TCC (=fTCC) 332 (TCC 393) can attend the meeting (more clearly, on discussion and voting of other agenda items) in İmregün, 'Yetersayılar' (n 1) 287.

See Halil Arslanl1, Anonim Şirketler II-III: Anonim Şirketlerin Organizasyonu ve Tahviller (3rd, Fakülteler Matbaası 1960) 195; Domaniç (n 4) 614; Ömer Teoman, 'Anonim Ortaklık Yönetim Kurulu Üyelerinin Müzakerelere Katılma Yasağına (TTK 332) Aykırılığın Yaptırımı Nedir?’ (2010) 26 (4) Batider 5, 10; İmregün, 'Yetersayılar' (n 1) 287; Kırca (Şehirali Çelik and Manavgat) (n 1) 499; Özge Ayan, 6102 sayıl Türk Ticaret Kanunu Çerçevesinde Anonim Şirket Yönetim Kurulu Üyelerinin Sadakat Yükümlülüğ̈̈ ve Bu Yükümlülüğ̈̈n İhlalinin Sonuçları (Adalet 2013) 121-122; Ersin Çamoğlu (Reha Poroy and Ünal Tekinalp), Ortaklıklar Hukuku I (14th, Vedat 2019) N. 578.
} 
accompanied with the conclusion that a board of directors' resolution taken in breach of an absolutely mandatory law provision would also be conclusively null and void. In brief, if we accept TCC 393/1 as an absolute mandatory regulation, it should be concluded that an act in breach of this prohibition, i.e. taking the resolution with participation of the relevant board member or members in the discussions and voting, would, as a rule, cause the resolution to be null.

In fact, an opinion in doctrine says that, "with TCC 393 provision, the lawmaker aims at preventing a board of directors' resolution forming the basis of a transaction that would damage the company, consequently the purpose of provision prevents considering it as a rule that limits the sanction of its 'violation with compensations".

However, TCC 393/2 states that "(t)he board member who acts in breach of this provisions and the members who do not object to attendance of the relevant member at the meeting although there is a known objective conflict of interest, and the board members who take a decision on attendance of such member at the meeting shall be obliged to compensate the company against losses incurred thereby", stipulating that a violation of the prohibition would cause compensation liability ${ }^{9}$ of member or members ${ }^{10}(i)$ who attend the discussions and voting despite personal conflict of interest, (ii) who do not object to attendance of the relevant member at the discussions and voting despite the fact that the conflict of interest was objectively existing or who know a conflict of interest which is not so apparent.

According to another opinion, initiating from this provision of TCC 393/2, sanction for violation of the prohibition from attending the negotiations may only be compensation liability pursuant to express wording of TCC 393 (fTCC 332); and defending an invalidation sanction for any reason would be an interpretation that is against the lawmaker's expressed intention, balance of interests and the principle of sustaining transactions to the extent possible ${ }^{11}$. In addition, upon adopting the invalidation view, as the company would not incur any loss due to a null decision, then there would be no compensation responsibility, so one would have to say that TCC 393 provision would not have any meaning and would be inapplicable in that case $^{12}$. In brief, violation of TCC 393/1 would not cause the invalidation of the board of directors' resolution in any case whatsoever ${ }^{13}$.

\footnotetext{
See Kırca (Şehirali Çelik and Manavgat) (n 1) 499.

9 For the compensation liability to arise, in addition to violation of the provision of TCC 393/1, there must be a loss incurred as a result of such violation and there must be a causal link between the loss and the violation [See Domaniç (n 4) 616; Kırca (Şehirali Çelik and Manavgat) (n 1) 498].

10 On this matter, see and review Kırca (Şehirali Çelik and Manavgat) (n 1) 498.

11 See Teoman (n 7) 11-12.

12 See Teoman (n 7) 13-14; Mehmet Helvac1, Anonim Ortaklıkta Yönetim Kurulu Üyesinin Hukuki Sorumluluğu (2nd, Beta 2001) 74; Abuzer Kendigelen, Hukukî Mütalâalar, C. XI: 2010-2011 (On İki Levha 2013) 12.

13 See Domaniç on the view that fTCC 332 (TCC 393) provides for a weak sanction comprising compensation, and that the decisions taken with attendance of the prohibited member or members at the meeting would remain effective [Domaniç ( $\mathrm{n}$ 4) 616]; see Kendigelen on the view that nullity is not the case under the fTCC 332/2 provision [Kendigelen (n 12) 12].
} 
We agree with this last view for the same reasons. In our opinion, had TCC 393/2 provided for only compensation responsibility as sanction of the prohibition from attending the negotiations, then we could have talked about nullity -as a rule- of the decisions taken with attendance of prohibited members. However, the lawmaker must not have wanted such a consequence which would automatically be the case if there was no provision on the sanction for the violation of prohibition, so it was clearly stated that they wanted to sustain the decision by providing for sanction for the violation of prohibition only ${ }^{14}$. So, in our opinion, TCC 393 may not be considered as an absolute mandatory provision, violation of which would cause nullity.

As it is apparent that there is no consensus in the doctrine, the judicial practice is also not consistent, on the matter. In some orders of the Supreme Court, it is said that the attendance at the meeting, of a board member who shouldn't attend the meeting within the scope of the prohibition from attending the negotiation, would not invalidate the decision taken, but only create compensation liability of the relevant member ${ }^{15}$, while some other orders mention nullity of the board of directors' resolution ${ }^{16}$.

\section{Effect of the Prohibition, on the Quorums, in light of the Legal Nature of the Provision}

Prohibition from attending the negotiations is related to meeting quorum as it prohibits presence of the member at the meeting with regard to the relevant agenda item, and also decision quorum as it also prevents the prohibited member from voting, according to the view that we agree with. Despite its importance, TCC has no provision on the effect of prohibition, on the quorums, both with regard to voting on the agenda item that causes the prohibition, and the doubt voting. Consequently, to answer the question as to whether the prohibited member or members would be taken into consideration in the meeting and decision quorums requires an interpretation. However, such interpretation is directly affected by the attitude taken on the legal nature of TCC 393/1 provision, due to its tight connection.

The opinion that considers TCC 393/1 as an absolute mandatory provision that invalidates (nullity) the decision upon its violation, takes an approach similar to "effect rule" in TCC 446/1-b, with regard to the effect of provision on the quorums, and considers that if it can be concluded that the decision complies sufficient meeting

\footnotetext{
14 See Teoman (n 7) 13.

15 See Supreme Court CommC, 8110/933, 18.02 .1954 [see Ersin Çamoğlu, Anonim Ortaklık Yönetim Kurulu Üyelerinin Hukuki Sorumluluğu (Kamu Borçlarından Sorumluluk İle) (3rd, Vedat 2010) 90 fn. 2]; Supreme Court 11th. CC, 20185733/7267, 18.11.2019 [see Arslan Kaya, İbrahim Çağrı Zengin, A. Furkan Sorkun, Nurgül Yıldız, M. Enes Yıldız and Elif Oğuz (Prepared by), Yargitay Hukuk Ve Ceza Dairelerinin Türk Ticaret Kanununa İlişskin Kararlarl (2019) (On İki Levha, 2020) 171].

16 See Supreme Court 11th. CC, 6106/6808, 25.12.1986 [Erdoğan Moroğlu and Abuzer Kendigelen, İçtihatll-Notlu Türk Ticaret Kanunu ve Illgili Mevzuat (10th, On İki Levha 2014) 291]; Supreme Court 11th. CC, 2009-2052/8497, 19.07.2010 (Lexpera); Supreme Court 11th. CC, 2377/5337, 27.09.1988 (Gönen Eriş, Ticari İşletme ve Şirketler, 2403); Supreme Court 11th. CC, 6108/6808, 25.12.1986 [Gönen Eriş, Açıklamal - İçtihatlı Ticari Işsletme ve Şirketler (2nd, Seçkin 2014) 2404].
} 
and decision quorums without attendance and vote of the member who actually attends the discussions and votes in favour of the decision (so with the attendance of other members and their votes in favour of the decision), then mere attendance at the meeting and voting despite the prohibition would not affect the validity of decisions taken, but otherwise, i.e. if the prohibited member has had an "effect" on taking the decision, then it would be required to deem the decision invalid ${ }^{17},{ }^{18}$.

It is seen that some of the authors having this view argue that prohibition should not be taken into consideration in calculation of the meeting and decision quorums, but they do not show any justification, and do not explain how "not taking into consideration" is to be implemented ${ }^{19}$. It may be thought that, not taking into consideration the attendance of prohibited members at the meeting or their voting rights, in calculation of quorums, means deducting the relevant number of members from the total number in calculation of quorums and then calculating the quorum after that, as is the case, e.g. in application of TCC 389/1 stipulating that own shares of the company shall not be taken into consideration in calculating general assemblies meeting quorum. In such case, e.g. two members are prohibited under TCC 393 at a board of directors of five members where legal quorums (TCC 390/1) are applicable, with regard to that agenda item, the majority of remaining three members, i.e. at least two members, would constitute meeting quorum, and the majority of attendants, i.e. again two members would constitute decision quorum. However, had these members been taken into consideration in calculation, the meeting quorum would be determined over five members, and accordingly be at least three members.

On the other hand, while the law expressly stipulates (TCC 393/2) that violation of the rule introduced by TCC 393/1 would only cause compensation liability, it is asserted that there is no need to argue whether the attendance of board members at the negotiations [and voting] despite the prohibition would affect the meeting [and decision] quorums or not, in fact, such a review would even cause concluding the invalidity of the board of directors' resolution, which consequently would be against the lawmaker's intention, wanting the decision to be valid and sanctioning

\footnotetext{
There are differing views as to the type of invalidity. One opinion considers that such violation would cause the decision to be null [see Gönen Eriş, Açıklamalı - İçtihatlı Uygulamalı Anonim Şirketler Hukuku (Adalet 1995) 276; Çamoğlu (Poroy and Tekinalp) (n 7) N. 578; Çoştan (n 2) 178], while the doctrine also states that non-existence would be the case in the same situation [see Kırca (Şehirali Çelik and Manavgat) (n 1) 499; also see Mehmet Bahtiyar, Ortaklıklar Hukuku (14th, Beta 2020) $250 \mathrm{fn} 408$ ]. In my opinion, even if we consider, for a moment, that violation of TCC 393/1 would invalidate the decision, it would be better to qualify the type of such invalidity as nullity. In fact, as the meeting and decision quorums would be achieved, even though with participation of the prohibited member(s), one should mention illegality on forming the will of the board of directors' rather than its' inexistence.

18 See Erişs, $A S ̧$ (n 17) 276; Çamoğlu (Poroy and Tekinalp) (n 7) N. 578; Çoştan (n 2) 178; Ayan (n 7) 131. Also see Supreme Court 11th. CC, 2377/5337, 27.09.1988.

19 See Sami Karahan, 'Anonim Şirketlerde Yönetim Kurulu Toplantı ve Karar Nisapları' in (ed.) Murat Yusuf Akın, Doç. Dr. Mehmet Somer'in Anısına Armağan, (2004-2006) 12 (1-3) Marmara Üniversitesi Hukuk Fakültesi Hukuk Araştırmaları Dergisi Armağan Özel Sayısı 173, 185; Çamoğlu (Poroy and Tekinalp) (n 7) N. 578. Also see İmregün, 'Yetersayılar' (n 1) 287 and Kırca (Şehirali Çelik and Manavgat) (n 1) 499 who mention that the vote of prohibited member would not be counted in calculation of decision quorum.
} 
the violation of prohibition with compensation only ${ }^{20}$. In brief, according to this view, TCC 393/1 provision should not be considered as a quorum matter; consequently the prohibition should not have any effect on the rules related to determining and calculating the quorums.

From this perspective, the consideration that TCC 393 is not absolutely mandatory, as we agree, prevents nullification with any justification on violation of the provision, and indirectly answers the question as to whether, in application of prohibition of attending the negotiations, the prohibited member would be taken into consideration in meeting and decision quorums or not. In fact, as it is not possible to conclude with nullification, if the prohibited member attends the meeting and casts a vote, such a decision should have to be deemed valid as to quorums, even if this is effective in taking the decision. Then, it means that the attendance and vote of the prohibited member is taken into consideration in calculation of meeting and decision quorums. For example, regarding an agenda item where three of five members are prohibited in the meaning of TCC 393, even if the three prohibited members attended the meeting, and the decision has been taken with affirmative votes of the two of them, this would not have any effect on the validity of the decision, but only the members would be liable for compensation under the conditions of TCC 393/2. However, had such members not been taken into consideration in calculation of quorum, the decision would not be considered validly taken due to lack of quorum in this example. As a result, in this view, in negotiations and the decision on the agenda item, all members must be taken into consideration in determining the quorum regarding the negotiations and voting in which they have participated, even if they are prohibited under TCC 393.

However, it is not possible, in our view, to say that this conclusion fully satisfies the sense of law. In fact, according to this view, the behaviour of a member who attends the meeting and votes, in violation of the prohibition imposed by the law, is almost being considered normal, deemed as if there is no breach of law. However, the attitude of a member who is prohibited in the meaning of TCC 393 and who complies with the prohibition and not does not attend the meeting, and does not cast vote, is almost being punished, as the prohibited members are taken into consideration in the calculation of the meeting and decision quorum, and makes the company unable to take decision. That is to say, if three members of a five-member board of directors are prohibited in the meaning of TCC 393, and does not attend the negotiation, and does not vote, as it should be, then such members -according to view that we adoptedwould be taken into consideration in determining quorums, i.e. they will be included in the total number for calculating the meeting quorum, so -assuming application of legal quorums (TCC 390/1)- the meeting quorum for that agenda item will be three

$\overline{20}$ See Teoman (n 7) 12. 
members, and the decision quorum will be determined as majority of attendees, and due to lack of meeting quorum, it would be impossible to discuss and then resolve that agenda item. Then, under the same conditions, with regard to quorums, decisions can be validly made when prohibition is not complied with, but there is risk of inability to take decisions due to lack of quorum when the prohibition is complied with. Also the fact that non-compliance with a rule becomes more advantageous than compliance, damages the sense of law.

As a way to overcome this injustice regarding non-compliance with the prohibition, it may be thought to prevent the occurrence of a relatively disadvantageous situation upon compliance with the prohibition. For this, it would be the best solution in our view, considering the balance of interests and the sense of justice, to take account of the prohibited members in the meaning of TCC 393, in determining quorums, when they attend the meeting and vote despite the prohibition, and not take them into account in determining quorums when they do comply with the prohibition and not attend the meeting and vote, and that the quorums must be calculated over the number found by deducting such members from the total.

Let's explain our conclusion with examples based on differing possibilities: At a board of directors of five members in total, subject to TCC 390/1 as to quorums, let's assume that two members are prohibited from negotiations regarding an agenda item. In the case where both prohibited members attend the meeting, their attendance shall be included in calculation of quorums, thus the meeting quorum will be three members, as the majority of five members. Accordingly, in addition to such two members, a meeting can be held with the presence of one more member who is not prohibited, and a decision can be made with the votes of two attending members -even if those members are prohibited from negotiations - in the same direction.

In a case where only one of the prohibited members attend the meeting, the member who complies with the prohibition and not attends the meeting shall be deducted from the full number of members in calculation of meeting quorum, thus the meeting quorum shall be determined over four members. Accordingly, such an agenda item may be discussed and voted with the attendance of three members, the simple majority of four members. Decision quorum is the majority of members present at the meeting, as the vote of members prohibited from negotiation will also be taken into consideration.

If both of the prohibited members comply with the prohibition and not attend the meeting, then those members shall be deducted from the full number of members, the base of meeting quorum, and consequently the necessary meeting quorum shall be determined as majority of three members, that is two, while the decision quorum shall be the majority of attending members. 
It should be mentioned that the consequence reached on the effect of negotiations prohibition on the meeting and decision quorums is also fully applicable when the quorums are stricter under the articles of association. In this regard, if the articles of association stated that, for example, the board of directors shall convene with attendance of all members and resolve with unanimous decision, then the prohibited members who attend the meeting are to be taken into consideration in calculating the quorums, and the members who do not attend the meeting due to prohibition are to be deducted from the total and the board of directors' meeting can be held with attendance of the remaining members, and resolution can be taken with an unanimous vote of attending members. If the articles of association requires a majority as meeting or decision quorum, that is stricter than simple majority but looser than unanimous decision (briefly, qualified majority), then the rate required under the articles of association, or if a specific number is mentioned, then the rate of such number in the total units may be adapted to the number arising from deducting the members not attending the meeting due to prohibition from the total, in order to determine the quorums. If, for example, articles of association has a provision that a board of directors of five members shall convene with four members, and two members do not attend the meeting due to prohibition, then the meeting quorum for discussing such agenda item must be calculated as $[(5-2) \times(4 / 5)=]$ three members.

\section{In cases where Decision is taken without Meeting}

Another issue to examine with regard to negotiation prohibition is whether this prohibition can, or how it can, be applied in case of decisions without meetings (resolving through circulation; TCC 390/4). As the prohibition from participating in negotiations primarily prevents the member from attending the discussions on the agenda item, for which it is prohibited, and there is no meeting and consequently no negotiation in case of decisions taken according to TCC 390/4 provision, it can be said that the prohibition may not be applied in case of resolving through circulation in this regard ${ }^{21}$. In fact, as members do not physically convene in the method of taking decision without meeting, and relevant member cannot affect other members or change their views, it may be considered that there is no possibility of damage on the interest intended to be protected with the provision on negotiation prohibition, therefore TCC 393 provision is not necessary in cases where decisions can be taken without meeting.

However, as it is accepted, prohibition of participating in negotiations also involves the prohibition of voting on that agenda item. Considering that there is no meeting to participate, it should be clear that prohibition of participating for a member under TCC 393 is only a prohibition of voting in cases where decision is taken through

\footnotetext{
$21 \quad$ See and review Akdağ Güney (n 4) 209
} 
circulation. It should be emphasized that the nature of prohibition here is not different from the participating in negotiations and voting prohibition which can be the case when the decision is taken through a meeting, and only the compensation liability would arise in case of violation, according to the view that we agree.

At this stage, it can be questioned whether the member prohibited from voting under TCC 393 should be included in the method of decision without meeting under TCC 390/4 or not. A view in the doctrine considers, without making a detailed explanation that a prohibited member cannot also participate in the decision-making without meeting ${ }^{22}$. It may be concluded from this view that the inclusion in the process of the prohibited member is not necessary, and even not possible, from the beginning, and consequently it is not even necessary to deliver the written decision proposal to the relevant member. As a basis for this view, it can be said that, even if the written proposal is delivered to the prohibited member and such member requests discussion of the matter at a meeting by the members, such member could not attend such a meeting because of TCC 393, in other words, in that case, relevant member would be requesting the discussion of the matter at a physical meeting where he/she is not allowed to attend or express his/her views at, so he/she has no interest to protect here; and therefore it is not necessary to deliver written decision proposal to a member who is not entitled to attend negotiations and vote, due to TCC 393, in a process of decision without meeting under TCC 390/4, and any member who, despite that, receives a proposal or otherwise becomes aware of the matter, would not be entitled to object to taking the decision with such method, and even if he/she so objects, this would not disable the circulation method, and the decision can be taken despite any such objection, provided that other conditions of TCC 390/4 are met.

But, such an attitude would not be accurate in our view. In fact, matters covered by TCC 393 basically requires interpretation, and as there is no example in the law on this matter, the possibility of being it mistake is high in determining whether or not a member is within the scope of prohibition on an agenda item, and due to such possibility, lawmaker specifically points to that issue, and introduces a special provision, and clearly leaves the final decision to the other members of the board of directors. While prohibition of participating in negotiations leaves the relevant member outside the process, by covering the negotiation and voting on an agenda item, it cannot be construed that the relevant member has no right to say on whether such prohibition is to be applied or not. If the member is of the opinion that there is a conflict of interest, he/she is required to disclose it before discussing the agenda item (TCC 393/1) and if he/she thinks that there is no conflict of interest, he/she should be able to express this at the board with his/her justifications, and defend himself/ herself. If the related member thinks there is no conflict of interest but some member

Domaniç (n 4) 614. 
or members think otherwise, then there is a doubt as to whether the matter is within the scope of negotiation prohibition or not, and doubt voting is a solution essentially for such situations.

Then, based on this provision which is not clear in the law as to scope and limits and requires interpretation based on legal knowledge, on whether or not it should be applied in each particular case, avoiding submission of written decision proposal under TCC 390/4 to a member would deprive him/her of expressing own views on whether the relevant member has a conflict of interest or not, and defend himself/herself if he thinks there is no such conflict of interest, which deprivation is not legitimate or excusable in our view. In addition, this may lead to relevant members not being aware of such a decision taken with that method, if other conditions are also fulfilled and the proposal turns into a decision. However, had such a decision been taken at a meeting, then the prohibited member who cannot attend the negotiations could at least know the subject being discussed, and learn about the outcome of the decision. When we go one step further, if delivery of a written decision proposal to the relevant member under TCC 393 provision is not deemed required, then this may be used/abused as a way of leaving the relevant member actually outside the management, based on a strained justification of prohibition. In addition to the foregoing reasons, considering that TCC 390/4 requires that a proposal should be delivered to all members without exception, it is necessary, for preserving the board's decision-making capacity, the member within the scope of TCC 393, just like all members, must be included in the process of decision without meeting, i.e. the written decision proposal must also be sent to him/her, otherwise it should be admitted that, it would not be possible to take decision with this method, and as this condition precedent under TCC 390/4 would not be fulfilled, the decision taken would be non-existent ${ }^{23}$.

At this point, it is concluded that, as a condition of the decision-making capacity, as to the method of decision without meeting, written decision proposal must be distributed to all members, and consequently, unlike the case where a decision is taken at a meeting, the prohibition under TCC 393 would not already have any effect on the meeting quorum in this method.

\footnotetext{
In this regard, just as the prohibition from participating in negotiations, in cases where the decision is taken through meeting, does not prevent from convocating the relevant board member to the meeting, and any attitude otherwise would cause non-existence of the decisions taken at the meeting (on this matter, see and review Supreme Court 11th. CC, 6772/12693, 02.07.2014 and see Kılıç Akyıldız who assesses the order [Gizem Kılıç Akyıldız, 'Karar İncelemesi: Bir Yönetim Kurulu Üyesinin Yönetim Kurulu Toplantısına Çağrılmaması ve Alınan Kararlara Etkisi', in (ed.) Demet Özdamar, Prof. Dr. Şeref Ertaş'a Armağan, (2017) 19 (Özel Sayı) 2299, 2305, 2309-2310]; and also on non-existence see Hediye Bahar Sayın, Pay Sahibi Haklarının Korunması Kapsamında Anonim Şirket Yönetim Kurulu Kararlarının Butlanı (2nd, On İki Levha 2017) 68-69; Aydın Alber Yüce Anonim Şirketlerde Yönetim Kurulu Kararlarının Butlanı (3rd, Seçkin 2018) 70, on nullity see Yüce (n 23) 68-69, same conclusion should be considered valid for the cases where the decision is through circulation. Also see and review Imregün who says that the proposal must mention any prohibition in the meaning of TCC 393, in cases where it is intended to take the decision through circulation [Oğuz İmregün, Anonim Ortakliklar (4th, Yasa 1989) 213].
} 
Regarding decision quorum, it is essentially not different from the case where the decision is taken at a meeting, and accordingly, we are of the opinion that, the member who casts vote in writing despite being prohibited must be taken into account in calculating quorums, and if the member complies with the prohibition and does not cast vote, then his/her vote should be deducted from the total number, and quorum should be determined according to the remaining number.

Hakem Değerlendirmesi: Dış bağımsız.

Çıkar Çatışması: Yazar çıkar çatışması bildirmemiştir.

Finansal Destek: Yazar bu çalışma için finansal destek almadığını beyan etmiştir.

Peer-review: Externally peer-reviewed.

Conflict of Interest: The author has no conflict of interest to declare.

Grant Support: The author declared that this study has received no financial support. 


\section{Bibliography}

Akdağ Güney N, Anonim Şirket Yönetim Kurulu (2nd, Vedat 2016).

Arslanlı H, Anonim Şirketler II-III: Anonim Şirketlerin Organizasyonu ve Tahviller (3rd, Fakülteler Matbaas1 1960).

Ayan Ö, 6102 sayılı Türk Ticaret Kanunu Çerçevesinde Anonim Şirket Yönetim Kurulu Üyelerinin Sadakat Yükümlülüğ̈̈ ve Bu Yükümlülügün İhlalinin Sonuçlarl (Adalet 2013).

Bahar Sayın H, Pay Sahibi Haklarının Korunması Kapsamında Anonim Şirket Yönetim Kurulu Kararlarının Butlanı (2nd, On İki Levha 2017).

Bahtiyar M, Ortakliklar Hukuku (14th, Beta 2020).

Çamoğlu E, Ortaklık Yönetim Kurulu Üyelerinin Hukuki Sorumluluğu (Kamu Borçlarından Sorumluluk Ille) (3rd, Vedat 2010).

Çoştan H, 'Yönetim Kurulunun Karar Alma Usulleri, Oy Hakk1, Yetersayılar ve Toplantı Talep Hakkı' (2012) 28 (3) Batider 155-190.

Domaniç H, Anonim Şirketler Hukuku ve Uygulaması, TTK. Şerhi II, (Yaylacık Matbaası 1988).

Eriş G, Açıklamalı - İçtihatlı Uygulamalı Anonim Şirketler Hukuku (Adalet 1995). (AŞ).

Eriş G, Açılklamalı - İçtihatlı Ticari İ̧sletme ve Şirketler (2nd, Seçkin 2014). (Ticari İ̧sletme ve Sirketler).

Helvacı M, Anonim Ortaklıkta Yönetim Kurulu Üyesinin Hukuki Sorumluluğu (2nd, Beta 2001).

İmregün O, Anonim Ortaklıklar (4th, Yasa 1989). (AO).

İmregün O, 'Anonim Ortaklıklarda Yönetim Kurulu Toplantı ve Karar Yetersayıları ve Yönetim Kurulu Kararlarına Karşı Başvuru Yolları' in Abuzer Kendigelen (ed), Prof. Dr. Hayri Domaniç'e 80. Yaş Günü Armağanı (Beta 2001) 272-292. (Yetersayılar).

Karahan S, 'Anonim Şirketlerde Yönetim Kurulu Toplantı ve Karar Nisapları' in (ed.) Murat Yusuf Akın, Doç. Dr. Mehmet Somer 'in Anısına Armağan, (2004-2006) 12 (1-3) Marmara Üniversitesi Hukuk Fakültesi Hukuk Araştırmaları Dergisi Armağan Özel Sayısı 173-185.

Kaya A, Zengin İÇ, Sorkun AF, Yıldız N, Yıldız ME, Oğuz E (Prepared by), Yargıtay Hukuk Ve Ceza Dairelerinin Türk Ticaret Kanununa İlişkin Kararları (2019) (On İki Levha, 2020).

Kılıç Akyıldız G, 'Karar İncelemesi: Bir Yönetim Kurulu Üyesinin Yönetim Kurulu Toplantısına Çağrılmaması ve Alınan Kararlara Etkisi', in (ed.) Demet Özdamar, Prof. Dr. Şeref Ertaş'a Armağan, (2017) 19 (Özel Say1) 2299-2313.

Kırca İ, Şehirali Çelik FH and Manavgat Ç, Anonim Şirketler Hukuku, C. 1, Temel Kavram ve Illkeler, Kuruluş, Yönetim Kurulu (BTHAE 2013).

Kendigelen A, Hukukî Mütalâalar, C. XI: 2010-2011 (On İki Levha 2013).

Moroğlu, E and Kendigelen A, İçtihatl--Notlu Türk Ticaret Kanunu ve Illgili Mevzuat (10th, On İki Levha 2014).

Nomer, HN, Kişi Birliklerinde Genel Kurul Kararlarının Geçersizliğine İlişkin Temel Esaslar (Beta 2008).

Poroy R, Tekinalp Ü, Çamoğlu E, Ortaklıklar Hukuku I (14th, Vedat 2019).

Teoman Ö, 'Anonim Ortaklık Yönetim Kurulu Üyelerinin Müzakerelere Katılma Yasağına (TTK 332) Aykırılığın Yaptırımı Nedir?’ (2010) 26 (4) Batider 5-14.

Yüce AA, Anonim Şirketlerde Yönetim Kurulu Kararlarının Butlanı (3rd, Seçkin 2018). 
